\title{
STRATEGI PENGEMBANGAN PEMASARAN PUPUK KOMPOS ORGANIK PADA YAYASAN PEMILAHAN SAMPAH TEMESI, KABUPATEN GIANYAR
}

\author{
Marketing Development Strategy Organic Compost Fertilizer of Yayasan \\ Pemilahan Sampah Temesi, Gianyar Regency
}

\author{
Paksi Bali Dewa*, I Made Sudarma, I Dewa Putu Oka Suardi
}

Program Studi Magister Agribisnis, Fakultas Pertanian, Universitas Udayana,Bali, Indonesia

*Email: paksibalidewa@gmail.com

\begin{abstract}
The waste problem is not only related to the production and its transportation, but also concerning the sorting of organic and non-organic types. Temesi landfills in Gianyar Regency through the Yayasan Pemilahan Sampah Temesi (YPST) has a waste sorting activity to be used as a more economical product, namely compost fertilizer "Temesi Organik". The organic fertilizers usage in Bali Province in the last five years (2013-2017) has always been with an average of 28,897 tons. This potential will be a marketing opportunity for organic fertilizer producers in Bali Province. But YPST facing a problem lack of good planning in terms of product marketing. The purpose of this study was to analyze internal and external factors, formulate alternative strategies, and determine the priority strategies in developing marketing of compost fertilizer "Temesi Organik". Data analysis methods used are SWOT and AHP analysis. The results of the study based on the SWOT analysis obtained six alternative strategies namely improving product quality to maintain customer loyalty and the synergy of government policies, maintaining product continuity to reach the organic fertilizers market potential, maintaining the legality of organic certification, expanding market networks by utilizing social media and word of mouth marketing methods, complementing facilities and production infrastructure in composting, and improving the quality of human resources to produce products with a strong bargaining position. Based on AHP analysis obtained the main priority of six alternative strategies is to expand the market network by utilizing social media and the word of mouth marketing method.
\end{abstract}

Keywords: Marketing Strategy, Organic Compost Fertilizer, Yayasan Pemilahan Sampah Temesi

\begin{abstract}
ABSTRAK
Permasalahan sampah tidak hanya terkait dengan produksi maupun keterangkutannya, tetapi juga menyangkut pemilahan terhadap jenis organik dan nonorganik. Tempat Pembuangan Akhir (TPA) Temesi di Kabupaten Gianyar melalui Yayasan Pemilahan Sampah Temesi (YPST) memiliki aktivitas pemilahan sampah untuk dijadikan sebagai produk yang lebih bernilai ekonomis yaitu pupuk kompos "Temesi Organik". Rata-rata penggunaan pupuk organik di Provinsi Bali dalam kurun waktu lima tahun terakhir (2013-2017) adalah 28.897 ton. Potensi ini akan menjadi peluang pemasaran bagi produsen pupuk organik di Provinsi Bali. Akan tetapi YPST menghadapi masalah yaitu kurangnya perencanaan yang baik dalam hal pemasaran produk. Tujuan dari penelitian ini untuk menganalisis faktor internal dan eksternal, merumuskan alternatif strategi, serta menentukan prioritas strategi dalam pengembangan pemasaran pupuk kompos "Temesi Organik". Metode analisis data yang digunakan adalah analisis SWOT dan AHP. Hasil penelitian berdasarkan analisis SWOT didapatkan enam alternatif strategi yaitu meningkatkan kualitas produk untuk menjaga loyalitas konsumen dan sinergisitas kebijakan pemerintah, menjaga kontinuitas produk untuk meraih potensi pasar pupuk organik, mempertahankan legalitas sertifikasi organik, memperluas jaringan pasar dengan memanfaatkan media sosial dan metode word of mouth marketing, melengkapi sarana dan prasarana produksi dalam pengkomposan, serta meningkatkan kualitas SDM untuk menghasilkan produk dengan posisi tawar yang kuat. Berdasarkan analisis AHP didapatkan prioritas utama dari keenam alternatif strategi tersebut yaitu memperluas jaringan pasar dengan memanfaatkan media sosial serta metode word of mouth marketing.
\end{abstract}

Kata kunci : Strategi Pemasaran, Pupuk Kompos Organik, Yayasan Pemilahan Sampah Temesi 


\section{PENDAHULUAN}

Sampah merupakan permasalahan utama yang dihadapi oleh hampir seluruh perkotaan di Indonesia. Bali sebagai salah satu daerah tujuan wisata di Indonesia, memiliki tanggung jawab besar dalam penanggulangan sampah. Sampah yang tidak terkelola akan merusak ekosistem lingkungan dan berdampak pada kesehatan manusia. Permasalahan sampah tidak hanya terkait dengan produksi maupun keterangkutannya, tapi masalah pemilahan terhadap jenis organik dan nonorganik serta pendaurulangan menjadi sesuatu yang berguna.

Salah satu Tempat Pembuangan Akhir (TPA) yang terletak di Kabupaten Gianyar yaitu TPA Temesi. Selain menjadi tujuan akhir sampah, TPA Temesi juga melakukan penanganan sampah yang dikelola oleh Yayasan Pemilahan Sampah Temesi (YPST). Aktivitas utama yang dimiliki YPST melalui Unit Fasilitas Pengolahan Sampah Temesi (UFPST) yaitu dengan memanfaatkan sampah organik menjadi pupuk kompos "Temesi Organik".

Fasilitas YPST beroperasi berpedoman pada sistem kualitas ISO 9000 dan memiliki laboratorium analitik dilapangan untuk menjamin kualitas kompos terbaik. YPST memiliki izin dari Kementrian Pertanian Republik Indonesia, melalui Kementan No 250.OL/Kpts/SP/310/B/06/206. Pada tanggal 1 Juni 2018 YPST juga memperoleh sertifikasi organik untuk produk pupuk kompos yang diproduksi dari Lembaga Sertifikasi Organik (LSO) Inofice, Bogor.

Data dari Badan Pusat Statistik dan Dinas Tanaman Pangan, Hortikultura, dan Perkebunan Provinsi Bali (2017), jumlah pupuk yang disubsidi oleh pemerintah dalam kurun waktu 2013-2017 mencapai 11.095 ton setiap tahunnya untuk ratarata luas lahan sawah 22.190 ha, sedangkan luas lahan sawah di Bali mencapai rata-rata 79.984 ha, sehingga masih terdapat kebutuhan pupuk organik di Bali yaitu dengan rata-rata 28.897 ton yang belum disubsidi oleh pemerintah.

Fenomena ini akan menjadi peluang pemasaran pupuk organik bagi produsen lokal salah satunya YPST. Akan tetapi, YPST menghadapi masalah yaitu kurangnya perencanaan yang baik dalam hal pemasaran produk. Hal ini terlihat dari realisasi penjualan pupuk kompos "Temesi Organik" dalam lima tahun terakhir (2013-2017) masih rendah dibandingkan target produksinya. Pencapaian tertinggi penjualan didapatkan pada tahun 2013 yang mencapai $68,5 \%$ yaitu sekitar 548 ton, sedangkan target produksi mencapai 800 ton setiap tahunnya.

Perlu terdapat upaya perbaikan dari manajemen YPST dalam hal merumuskan strategi pemasarann yang tepat agar mampu memperluas jaringan pasar, meningkatkan penjualan, dan bersaing dengan produsen pupuk organik dari daerah lain. Penelitian ini bertujuan untuk menyusun strategi pengembangan pemasaran yang efektif dan efisien agar pupuk kompos "Temesi Organik" dapat terserap maksimal oleh pasar.

\section{METODE PENELITIAN}

Rancangan penelitian yang digunakan adalah analisis deskriptif kualitatif dan menggunakan sumber data primer serta sekunder. Penentuan responden dari pihak internal dan eksternal menggunakan teknik purposive samplings sehingga diperoleh 20 orang. Penelitian ini menggunakan jenis data kuantitatif dan kualitatif dengan metode wawancara, Focus Group Discusion (FGD), observasi lapangan, dokumenasi, dan studi pustaka serta dianalisis melalui tiga tahapan yakni input stage menggunakan matriks IFE, EFE, matching stage dengan analisis matriks IE dan analisis SWOT, serta Decision Stage melalui analisis AHP.

\section{HASIL DAN PEMBAHASAN}

Evaluasi Faktor Internal (IFE) dan Evaluasi Faktor Eksternal (EFE) Strategi Pengembangan Pemasaran Pupuk Kompos "Temesi Organik"

Tabel 1. Matriks IFE Strategi Pengembangan Pemasaran Pupuk Kompos "Temesi Organik"

\begin{tabular}{|c|c|c|c|c|c|}
\hline \multirow{2}{*}{ No } & Faktor Internal & \multirow{2}{*}{ Bobot } & \multirow{2}{*}{ Rating } & \multirow{2}{*}{ Skor } & \multirow{2}{*}{ Peringkat } \\
\hline & Faktor Kekuatan & & & & \\
\hline 1 & $\begin{array}{l}\text { Kualitas Produk yang sudah } \\
\text { Bersertifikat Resmi Organik }\end{array}$ & 0.117 & 4 & 0.468 & 1 \\
\hline 2 & Kontinuitas Produk & 0.111 & 3 & 0.333 & 2 \\
\hline 3 & Lokasi Produksiyang Strategis & 0.099 & 3 & 0.297 & 3 \\
\hline 4 & $\begin{array}{l}\text { Survailen Berkala dari Pihak } \\
\text { Lembaga Sertifikasi Organik }\end{array}$ & 0.082 & 3 & 0.246 & 5 \\
\hline \multirow[t]{3}{*}{5} & $\begin{array}{l}\text { Dukungan dari Stakeholder } \\
\text { Pemerhati Lingkungan }\end{array}$ & 0.092 & 3 & 0.276 & 4 \\
\hline & Total Kekuatan & 0.501 & & & \\
\hline & Faktor Kelemahan & & & & \\
\hline 1 & $\begin{array}{l}\text { Janingan PemasaranMasih } \\
\text { Terbatas }\end{array}$ & 0.120 & 2 & 0.240 & 3 \\
\hline 2 & $\begin{array}{l}\text { Sarana dan Prasarana Produksi } \\
\text { Kurang Lengkap }\end{array}$ & 0.084 & 2 & 0.168 & 4 \\
\hline 3 & Terbatasnya Kegiatan Promosi & 0.124 & 3 & 0.372 & 1 \\
\hline 4 & $\begin{array}{l}\text { TampilanKemasanyangMasih } \\
\text { Sederhana }\end{array}$ & 0.073 & 2 & 0.146 & 5 \\
\hline \multirow[t]{3}{*}{5} & $\begin{array}{l}\text { Kurang Adanya Pelatihan } \\
\text { Manajemen dan Bahasa Inggiis } \\
\text { pada Tenaga Teknis Yayasan }\end{array}$ & 0.098 & 3 & 0.294 & 2 \\
\hline & Total Kelemahan & 0.499 & & & \\
\hline & Total IFE & 1.00 & & 2.84 & \\
\hline
\end{tabular}

Rangkuti (2008) menetapkan bahwa total skor berdasarkan matriks evaluasi faktor internal minimal 2,50. Apabila total skor berada di bawah 2,50 berarti menandakan secara internal perusahaan adalah lemah, sedangkan nilai yang berada diatas 2,50 menunjukkan posisi internal yang kuat. Tabel 1 menunjukkan total skor matriks IFE pada strategi pengembangan pemasaran pupuk kompos "Temesi Organik" adalah 2,84 yang berarti YPST mempunyai kemampuan baik dalam mengantisispasi kelemahan internal. Produk yang memiliki sertifikat organik (skor 0,468), kontinuitas produk (skor 0,333), dan dukungan lokasi produksi strategis (skor 0,297) menjadi kekuatan utama yang dimiliki oleh YPST 
dalam menghadapi persaingan pasar pupuk organik dan mengupayakan pelayanan terhadap konsumen secara optimal. Kelemahan utama YPST terdapat pada parameter terbatasnya kegiatan promosi (skor 0,372), kurang adanya pelatihan SDM Yayasan $(0,294)$, dan terbatasnya jaringan pemasaran $(0,240)$. YPST belum maksimal memanfaatkan media promosi terlihat dari minimnya aktivitas pemasaran di media sosial. Faktor SDM masih perlu ditingkatkan agar semakin bersaing dalam dunia bisnis serta mampu menangkap peluang dengan pengetahuan bahasa Inggris. Jaringan pemasaran yang masih terbatas merupakan salah satu dampak dari kegiatan promosi yang belum maksimal.

Tabel 2 menunjukan bahwa YPST mampu memanfaatkan peluang untuk menghindari ancaman karena skor matriks EFE berada diatas 2,50 yaitu 2,72 . Hasil penelitian menunjukkan loyalitas konsumen (skor 0,460), potensi pasar pupuk organik (skor 0,318), dan kebijakan pemerintah terhadap pertanian organik (skor 0,306 ) memperoleh ranking tertinggi sehingga Yayasan perlu memanfaatkan dengan baik parameterparameter tersebut untuk memaksimalkan pemasaran pupuk kompos "Temesi Organik". Sedangkan faktor ancaman yang perlu lebih mendapatkan perhatian yaitu tingginya biaya produksi dalam pengomposan (skor 0,300), pesaing dari perusahaan sejenis (skor 0,252 ), dan ketersediaan tenaga kerja pemilah sampah (skor 0,212). Produksi kompos memerlukan banyak biaya dikarenakan sampah yang datang ke TPA Temesi masih tercampur dengan bahan anorganik sehingga perlu membeli organik dengan memperkerjakan tenaga pemilah. YPST perlu menjaga dan meningkatkan inovasi produk untuk menghadapi keberadaan dari produsen sejenis, agar tetap mampu bersaing dalam pemasaran pupuk organik di Provinsi Bali

Tabel 2. Matriks EFE Strategi Pengembangan Pemasaran Pupuk Kompos "Temesi Organik"

\begin{tabular}{|c|c|c|c|c|c|}
\hline \multirow{2}{*}{ No } & Faktor Eksternal & \multirow{2}{*}{ Bobot } & \multirow{2}{*}{ Rating } & \multirow{2}{*}{ Skor } & \multirow{2}{*}{ Peringkat } \\
\hline & Faktor Peluang & & & & \\
\hline 1 & $\begin{array}{l}\text { Meminimalisir Volume Sampah } \\
\text { Organik }\end{array}$ & 0.084 & 3 & 0.252 & 5 \\
\hline 2 & $\begin{array}{l}\text { Potensi Pasar Pupuk Organik } \\
\text { yang Masih Tersedia }\end{array}$ & 0.106 & 3 & 0.318 & 2 \\
\hline 3 & $\begin{array}{l}\text { Loyalitas Konsumen Terhadap } \\
\text { Merek Tinggi }\end{array}$ & 0.115 & 4 & 0.460 & 1 \\
\hline 4 & $\begin{array}{l}\text { Perkembangan Media } \\
\text { Komunikasi Sosial }\end{array}$ & 0.094 & 3 & 0.282 & 4 \\
\hline \multirow[t]{3}{*}{5} & $\begin{array}{l}\text { Kebijakan Pemerintah Terhadap } \\
\text { Pertanian Organik }\end{array}$ & 0.102 & 3 & 0.306 & 3 \\
\hline & $\begin{array}{l}\text { Total Peluang } \\
\end{array}$ & 0.501 & & & \\
\hline & Faktor Ancaman & & & & \\
\hline 1 & $\begin{array}{lcc}\text { Kualitas } & \text { Bahan } & \text { Baku yang } \\
\text { Masih Tercampur } & \text { Kandungan } \\
\text { Kimia } & & \end{array}$ & 0.086 & 2 & 0.172 & 4 \\
\hline 2 & $\begin{array}{l}\text { Ketersediaan Tenaga Kerja } \\
\text { Pemilah Sampah Tidak Menentu }\end{array}$ & 0.106 & 2 & 0.212 & 3 \\
\hline 3 & Pesaing dari Perusahaan Sejenis & 0.126 & 2 & 0.252 & 2 \\
\hline 4 & $\begin{array}{l}\text { Tingginya Biaya Produksi dalam } \\
\text { Pengomposan }\end{array}$ & 0.100 & 3 & 0.300 & 1 \\
\hline 5 & $\begin{array}{l}\text { Posisi Tawar Konsumen } \\
\text { Semakin Kuat }\end{array}$ & 0.082 & 2 & 0.164 & 5 \\
\hline & Total Ancaman & 0.500 & & & \\
\hline & Total EFE & 1.00 & & 2.72 & \\
\hline
\end{tabular}

Matriks Internal dan Eksternal (IE) Strategi Pengembangan Pemasaran Pupuk Kompos "Temesi Organik"

Hasil matriks IE yang dapat dilihat pada Gambar 1, menunjukkan bahwa YPST dalam upaya pengembangan pemasaran pupuk kompos "Temesi Organik" berada pada sel V, sehingga strategi yang layak digunakan adalah penetrasi pasar, pertahankan, dan pelihara. Strategi penetrasi pasar merupakan salah satu upaya yang dapat dilakukan YPST untuk meningkatkan penjualan produk dengan potensi pasar pupuk organik yang telah tersedia melalui usaha-usaha pemasaran lebih agresif.

Strategi pertahanan dan pelihara melalui upaya memperbaiki atau meningkatkan kualitas produk dan jasa/pelayanan yang sudah ada. Strategi ini tepat direkomendasikan karena YPST masih perlu mempertahankan konsistensi dalam menerapkan organik, agar tidak lagi ditemukan campuran sampah plastik pada produk pupuk kompos organik yang diproduksi. Dalam bidang pelayanan, khusus pada saat pemasaran, perlu ditambahkan kegiatan presentasi dan penjelasan lebih lanjut mengenai kelebihan pupuk kompos "Temesi Organik" beserta cara pengaplikasiannya.

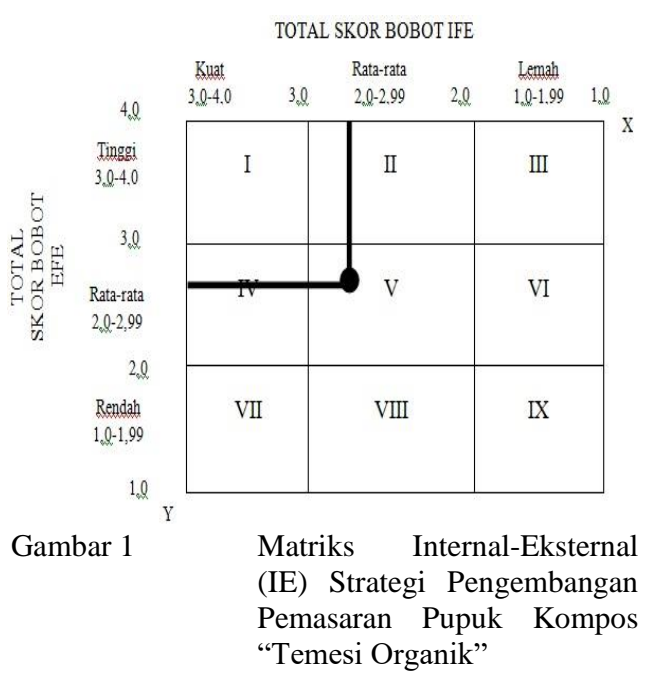

Alternatif Strategi Pengembangan Pemasaran Pupuk Kompos "Temesi Organik"

Strategi alternatif yang disarankan yaitu strategi S-O, S-T, W-O dan W-T, yang disajikan pada Gambar 2

Strategi Strengths-Opportunity (S-O)

a. Meningkatkan Kualitas Produk untuk

Menjaga Loyalitas Konsumen serta

Sinergisitas Kebijakan Pemerintah

sehingga Permintaan Pupuk

Berkelanjutan

Setiap pelaku usaha bisnis pada umumnya dihadapkan dalam persaingan serta 
kemampuan dalam memenuhi kebutuhan pelanggan yang dipengaruhi oleh tingkat mutu produk. Peningkatkan kualitas pupuk kompos "Temesi Organik" yang mampu dilakukan setidaknya akan mengurangi penilaian negatif sehingga menghindari hilangnya konsumen dan tetap menjaga kerjasama dengan pemerintah terkait pengadaan pupuk organik bersubsidi.

b. Menjaga Kontinuitas Produk Didukung

Lokasi Produksi untuk Meraih Potensi Pasar Pupuk Organik

Kemampuan menyediakan produk yang secara berkelanjutan akan menjadi keunggulan tersendiri bagi YPST untuk menjaga posisi sebagai salah satu produsen dalam pemasaran pupuk organik di Bali, sehingga potensi pasar yang masih tersedia dapat dimaksimalkan.

\section{Strategi Strengths-Threaths (S-T)}

a. Mempertahankan Legalitas Sertifikasi Organik dalam Menghadapi Persaingan

YPST perlu mempertahankan atau melanjutkan sertifikat organik yang sudah mereka dapatkan ketika masa berlakunya telah habis, karena secara tidak langsung YPST melindungi konsumen atau pelanggan dari produk pupuk organik yang ilegal.

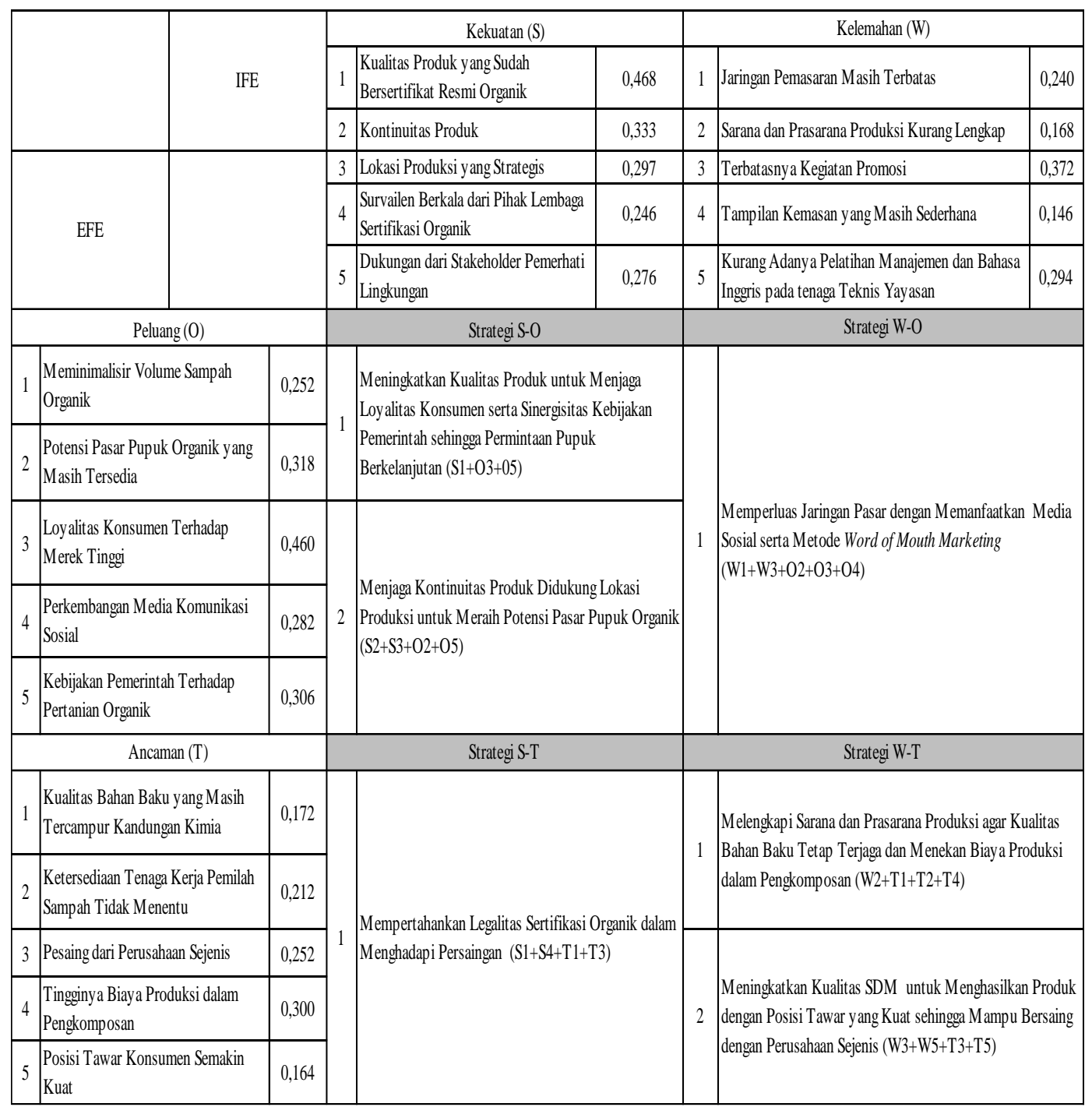

Gambar 2 Analisis SWOT Strategi Pengembangan Pemasaran Pupuk Kompos "Temesi Organik" 


\section{Strategi W-O (Weakness-Opportunities)}

a. Memperluas Jaringan Pasar dengan Memanfaatkan Media Sosial serta Metode Word of Mouth Marketing

Memaksimalkan perkembangan teknologi yang ada dewasa ini, terutama teknologi informasi (internet), diharapkan dapat membantu YPST mengetahui informasi jaringan pasar dengan konsumen pupuk organik yang potensial. Kemudahan memanfaatkan banyak aplikasi sosial media pada internet dan tidak memerlukan biaya tinggi untuk mengunakannya, perlu didukung dengan SDM yang mahir mengakses aplikasi media sosial tersebut. Sedangkan dalam metode word of mouth marketing, lebih diharapkan dari pembicaraan yang mengalir secara alami berdasarkan kualitas positif sebuah produk dalam hal ini pupuk kompos "Temesi Organik".

\section{Strategi W-T (Weakness-Treaths)}

a. Melengkapi Sarana dan Prasarana Produksi agar Kualitas Bahan Baku Tetap Terjaga dan Menekan Biaya Produksi dalam Pengkomposan

Tuntutan bekerja secara efisien tidak dapat dihindari dalam bisnis modern, apabila sering dijumpai bahwa biaya produksi terus mengalami peningkatan. Sarana dan prasarana yang lengkap berperan penting dalam menekan biaya produksi dan mengatasi permasalahan jumlah tenaga pemilah sampah yang tidak menentu. Selain karena mempercepat proses pelaksanaan pekerjaan sehingga mampu menghemat waktu, meningkatkan produktivitas barang maupun jasa, juga

dapat menghasilkan kinerja lebih berkualitas dan terjamin.

b. Meningkatkan Kualitas SDM untuk Menghasilkan Produk dengan Posisi Tawar yang Kuat Sehingga Mampu Bersaing dengan Perusahaan Sejenis

Menghadapi persaingan pasar, pupuk kompos "Temesi Organik" harus mampu memiliki nilai tawar atau value proposition yang kuat. Salah satu pemilihan dan penerapan strategi pengembangan pemasaran yang sudah ditentukan, akan sangat dipengaruhi oleh kualitas SDM YPST sebagai pelaksana baik itu dalam kegiatan produksi, pemasaran, hingga pada jasa pelayanan.

Prioritas Strategi Pengembangan Pemasaran Pupuk Kompos "Temesi Organik"
Hasil analisis AHP terhadap strategi pengembangan pemasaran pupuk kompos "Temesi Organik" dapat dilihat pada Gambar 3, beserta berikut penjelasannya pada setiap level.

\section{Faktor penentu}

Faktor-faktor penentu terhadap pengembangan pemasaran pupuk kompos "Temesi Organik" ditentukan berdasarkan dua peringkat skor tertinggi dari parameter matriks IFE dan EFE. Pada masing-masing faktor penentu diperoleh bobot skor dan ranking prioritas sebagai berikut.

F1. Potensi Pasar Pupuk Organik yang Masih Tersedia

Memiliki nilai prioritas tertinggi dengan bobot 0,356 menunjukkan peluang pasar pupuk organik yang masih tersedia berpengaruh dalam keberhasilan strategi pengembangan pemasaran pupuk kompos "Temesi Organik". Hal ini didukung dengan adanya Peraturan Gubernur Bali Nomor 16 Tahun 2013 untuk menjaga potensi penggunaan pupuk organik oleh masyarakat terutama yang beraktivitas pada sektor pertanian. Selain itu, karena Bali memiliki keunggulan pada sektor pariwisata, beberapa hotel, villa, maupun restoran mulai membuat kebun organik didalam usaha mereka.

\section{F2. Terbatasnya Kegiatan Promosi}

Faktor prioritas tertinggi kedua yaitu terbatasnya kegiatan promosi dengan bobot 0,235 . Faktor ini menentukan keberhasilan strategi pengembangan pemasaran pupuk kompos "Temesi Organik", karena apabila dengan minimnya promosi yang dilakukan, akan membatasi jaringan pemasaran itu sendiri, akibat ketidaktahuan masyarakat akan pupuk yang diproduksi oleh YPST.

F3. Loyalitas Konsumen terhadap Merek Tinggi

Faktor prioritas ketiga selanjutnya yaitu terkait loyalitas konsumen dengan bobot 0,155 . Faktor ini menentukan karena menjual pupuk kompos "Temesi Organik" kepada pelanggan lama tentunya lebih mudah dibandingkan menjual kepada pelanggan baru sehingga YPST harus konsisten dalam menyajikan produk pupuk yang berkualitas dan mampu memberikan pelayanannya yang terbaik.

F4. Kualitas Produk yang Sudah Bersertifikat Resmi Organik

Faktor prioritas keempat dengan bobot 0,101 yaitu kualitas produk yang sudah memiliki sertifikat resmi organik. Faktor ini menentukan, karena kepemilikan sertifikat akan membedakan pupuk kompos "Temesi Organik" dengan produk sejenis yang 
beredar dipasaran, serta memiliki nilai tambah dengan status keorganikannya yang tidak diragukan oleh konsumen.

\section{F5. Kontinuitas Produk}

Faktor prioritas kelima yaitu kontinuitas produk dengan bobot 0,065. Faktor ini mempengaruhi dalam strategi pengembangan pemasaran pupuk kompos "Temesi Organik" karena dengan kemampuan memproduksi yang secara berkelanjutan akan menghindari konsumen dari rasa kecewa apabila tidak mendapatkan pupuk ketika membeli dengan volume tertentu serta dapat mempertahankan kerjasama YPST dengan pemerintah dalam mengikuti program subsidi pupuk organik.

F6. Tingginya Biaya Produksi dalam Pengkomposan

Faktor prioritas keenam yaitu tingginya biaya produksi dalam pengomposan dengan bobot 0,042 . Berdasarkan hasil penelitian biaya terbesar yang dihadapi adalah untuk membayar tenaga pemilah sampah. Seperti yang diketahui bahan baku kompos merupakan hasi pemilahan dari sampah organik dan anorganik pada TPA Temesi, hal ini perlu dukungan dari kesadaran masyarakat khususnya di Kota Gianyar dalam membuang sampah agar terdapat pemilahan terlebih dahulu ditingkat rumah tangga.

\section{F7. Pesaing dari Perusahaan Sejenis}

Faktor prioritas ketujuh dengan bobot 0,027 yaitu pesaing dari perusahaan sejenis. Berdasarkan hasil penelitian keberadaan produk sejenis yang sudah banyak terdapat dipasaran, justru menjadi motivasi bagi YPST agar tetap bersaing secara sehat. Namun perlu diwaspadai, agar jaringan pemasaran yang sudah dimiliki tidak tergantikan.

F8. Kurang Adanya Pelatihan Manajemen dan Bahasa Inggris pada Tenaga Teknis Yayasan

Faktor prioritas terakhir yaitu terkait dengan kualitas SDM teknis Yayasan yang masih memerlukan kegiatan pelatihan terkait manajemen dan bahasa Inggris dengan bobot 0,020 . Kemampuan manajemen yang baik, dapat membantu menjaga situasi YPST agar tetap terhindar dari kerugian dan meningkatkan ide-ide untuk berinovasi. Sedangkan melalui kemampuan bahasa Inggris dapat menambah keterampilan dalam membangun kemitraan bisnis serta mengoperasikan internet/media sosial sebagai salah satu media untuk menambah jaringan pemasaran.

\section{Aktor Penentu}

Level aktor atau pelaku yang dapat menentukan strategi pengembangan pemasaran pupuk kompos "Temesi Organik", baik itu yang terlibat langsung maupun tidak langsung berdasarkan proses analisis AHP diperoleh ranking bobot sebagai berikut.

\section{A1. Yayasan Pemilahan Sampah Temesi}

Pelaku atau aktor yang memperoleh prioritas pertama paling menentukan adalah pihak Yayasan sendiri dengan bobot 0,534. Setiap alternatif strategi yang sudah dirumuskan kemudian dilanjutkan dengan menyusun peringkat prioritas, akan sia-sia apabila pihak YPST tidak menerapkannya. Melalui penelitian ini, diharapkan dapat memberikan gambaran dan masukan bagi YPST agar dapat memaksimalkan penyerapan pupuk kompos organik yang diproduksi.

\section{A2. Petani/Konsumen Pupuk Organik}

YPST saat ini memiliki segmentasi pasar yaitu petani sawah dan hortikultura. Sasaran lain adalah pelaku usaha yang bergerak pada bidang pertanian (kuliner dan tanaman hias). Apabila tidak ada lagi minat petani/konsumen dalam penggunaan input organik, maka akan berdampak pada pemasaran pupuk kompos "Temesi Organik", sehingga aktor ini berada pada prioritas ranking kedua dengan bobot 0,229.

\section{A3. Distributor}

Pelaku atau aktor yang memiliki prioritas ketiga yaitu pihak distributor dengan bobot 0,138. Distributor memiliki peran karena YPST dapat dimudahkan pada kegiatan promosi sekaligus pemasaran terutama pada wilayah yang belum terjangkau. 


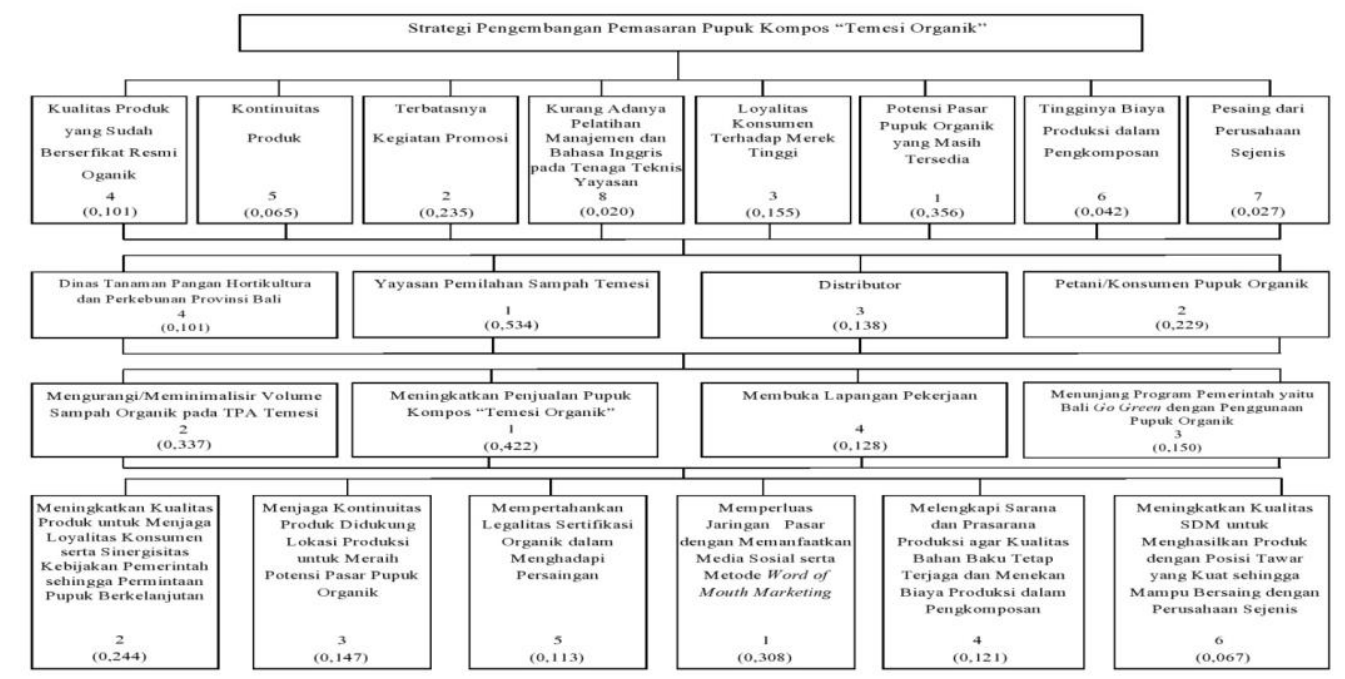

Gambar 3 Analisis AHP Strategi Pengembangan Pemasaran Pupuk Kompos "Temesi Organik"

A4. Dinas Tanaman Pangan, Hortikultura, dan Perkebunan Provinsi Bali

Pelaku atau aktor yang memiliki prioritas terakhir yaitu Dinas Tanaman Pangan, Hortikultura, dan Perkebunan Provinsi Bali dengan bobot 0,101 . Dinas provinsi perlu saling bekerjasama dengan dinas pertanian di tingkat kabupaten dalam memberikan informasi terkait potensi wilayah pertanian dengan kebutuhan pupuk organik yang signifikan kepada pihak YPST. Selain itu dinas perlu rutin melalukan pembinaan serta memfasilitasi petani atau kelompok tani (subak) yang sudah menerapkan pertanian organik terutama terkait pemasaran produk, agar penggunaan input organik salah satunya pupuk tetap berlanjut

\section{Tujuan}

Strategi pengembangan pemasaran pupuk kompos "Temesi Organik" mempunyai beberapa tujuan dengan ranking bobot sebagai berikut.

T1. Meningkatkan Penjualan Pupuk Kompos "Temesi Organik"

Tujuan yang memperoleh prioritas pertama yaitu meningkatkan penjualan pupuk kompos "Temesi Organik" dengan bobot yang diperoleh 0,422 . Melihat realisasi penjualan pupuk dalam kurun lima tahun terakhir (2013-2017) senantiasa berfluktuasi, sehingga pengembangan pemasaran merupakan upaya yang dapat dilakukan secara nyata.

T2. Mengurangi/Meminimalisir Volume Sampah Organik pada TPA Temesi

Tujuan prioritas kedua dengan bobot 0,337 adalah mengurangi/meminimalisir volume sampah organik pada TPA Temesi. YPST terdiri dari pengolahan

sampah anorganik dan organik, dengan kegiatan utama produksi pupuk kompos hasil pemilahan sampah organik. Terbukti dalam kurun lima tahun terakhir (20132017) mampu meminimalisir sampah organik dengan rata-rata mencapai 10.984 ton (Sumber: Yayasan Pemilahan Sampah Temesi, 2018). Diharapkan apabila pemasaran pupuk berjalan lancar, akan berdampak pada tujuan awal dari berdirinya YPST yaitu mengurangi/meminimalisir sampah organik pada TPA Temesi.

T3. Menunjang Program Pemerintah Yaitu Bali Go Green dengan Penggunaan Pupuk Organik

Tujuan prioritas ketiga melalui pencapaian bobot 0,150 adalah menunjang program pemerintah yaitu Bali Go Green dengan penggunaan pupuk organik.. YPST menjadikan peluang ini untuk semakin memperkenalkan pupuk kompos yang diproduksi beserta keunggulannya, disamping ikut berperan dalam upaya Pemerintah Provinsi Bali untuk meningkatkan penggunaan pupuk organik oleh petani.

\section{T4. Membuka Lapangan Pekerjaan}

Tujuan prioritas terakhir yaitu membuka lapangan pekerjan dengan pencapaian bobot 0,128 . Dari awal terbentuk, YPST sudah mampu menyediakan pekerjaan bagi masyarakat Desa Temesi untuk mengisi posisi internal Yayasan terutama pada tenaga teknis dan administrasi. YPST juga mampu memberikan lapangan pekerjaan bagi masyarakat luar Bali yang mengisi posisi sebagai tenaga pemilah sampah. 
Diharapkan akan kembali mampu membuka lapangan pekerjaan baik itu untuk tenaga tetap maupun harian sehingga kegiatan ekonomi tetap berjalan disertai dengan kondisi lingkungan diminimalisir dari penimbunan sampah.

\section{Prioritas Strategi}

Berdasarkan pada hasil perhitungan AHP dengan melihat faktor penentu, aktor, serta tujuan yang ingin dicapai maka diperoleh ranking bobot prioritas strategi sebagai berikut.

P1. Memperluas Jaringan Pasar dengan Memanfaatkan Media Sosial serta Metode Word of Mouth Marketing

Strategi ini memperoleh skor bobot pencapaian 0,308 sehingga berada pada prioritas ranking pertama. Dengan memanfaatkan media sosial, secara tidak langsung YPST dapat memberikan informasi tentang aktivitas dan pelayanan apa yang dilakukan. Agar strategi ini tidak sia-sia ketika diterapkan, perlu ada beberapa pertimbangan diantaranya menentukan satu sosial media utama, pemilihan konten, dan pemilihan waktu untuk mengunggah. Keberhasilan menerapkan metode selanjutnya yaitu word of mouth marketing, YPST perlu memberikan kesan menarik dari pupuk yang diproduksi dan mempunyai perbedaan dari produk sejenis sehingga layak untuk diperbincangkan oleh konsumen. Lengkapi dengan membuat produk pupuk yang berkualitas, ciptakan layanan yang prima, dan cepat menanggapi serta memperbaiki apabila terjadi permasalahan dengan konsumen.

P2. Meningkatkan Kualitas Produk untuk Menjaga Loyalitas Konsumen serta Sinergisitas Kebijakan Pemerintah sehingga Permintaan Pupuk Berkelanjutan

Prioritas strategi kedua ini memperoleh skor bobot 0,244 . Terdapat beberapa cara yang dapat dilakukan oleh YPST untuk meningkatkan kualitas pupuk yang diproduksi, yaitu dengan quality control, review konsumen, dan menilai suplier.

P3. Menjaga Kontinuitas Produk Didukung Lokasi Produksi untuk Meraih Potensi Pasar Pupuk Organik

Prioritas strategi ini memperoleh skor bobot pencapaian 0,147 . Terdapat tiga komponen sirkulasi produksi yang perlu diperhatikan oleh Yayasan dalam menjaga kontinuitas meliputi input, process, dan output.

P4. Melengkapi Sarana dan Prasarana Produksi agar Kualitas Bahan Baku Tetap
Terjaga dan Menekan Biaya Produksi dalam Pengkomposan

Prioritas strategi keempat memperoleh skor bobot 0,121 . Sarana yang perlu dilengkapi oleh YPST adalah mesin pemilah sampah. Terdapat dua jenis mesin pemilah sampah yang bisa dijadikan pertimbangan oleh YPST yaitu mesin Conveyor dan Mesin Pemilah Sampah "Pujo Bae". Pengadaan mesin pemilah sampah diharapkan mampu mengatasi ketersediaan tenaga pemilah yang tidak menentu sekaligus mengefisiensikan biaya produksi dan dapat menghasilkan sampah organik yang lebih berkualitas. Pada faktor prasarana dalam hal ini gudang penyimpanan bahan baku pupuk, YPST perlu melengkapi pembatas karena terletak dalam satu tempat dengan proses pengkomposan dan penyaringan.

P5. Mempertahankan Legalitas Sertifikasi Organik dalam Menghadapi Persaingan

Prioritas kelima memperoleh skor bobot 0,113. Pupuk kompos "Temesi Organik" terdaftar memiliki sertifikat organik sejak bulan Juni 2018 dengan masa berlaku tiga tahun, sangat diharapkan setelah selesai masa berlaku sertifikat tersebut untuk selanjutnya dapat diperpanjang lagi. Kepemilikan sertifikat organik pada produk yang diproduksi membuat Yayasan menjamin praktek perdagangan secara etis dan adil bagi produsen maupun konsumen serta terhindar dari pelanggaran hukum.

P6. Meningkatkan Kualitas SDM untuk Menghasilkan Produk dengan Posisi Tawar yang Kuat Sehingga Mampu Bersaing dengan Perusahaan Sejenis

Prioritas strategi terakhir memperoleh skor bobot 0,067 . Beberapa pelatihan manajemen yang dapat dilakukan oleh YPST agar mampu menghasilkan produk dengan posisi tawar yang kuat bagi konsumen yaitu manajemen produksi, manajemen pemasaran, dan manajemen keuangan. Kualitas SDM teknis Yayasan juga perlu ditingkatkan dengan pelatihan bahasa Inggris dan pelatihan akutansi keuangan karena berkaitan dengan kualitas pelayanan dan manajemen keunagan. Dengan penguasaan bahasa Inggris dan manajemen keuangan tersebut akan membantu meningkatkan kualitas branding dan sustainability keuangan dari produk pupuk kompos "Temesi Organik". 


\section{SIMPULAN DAN SARAN}

\section{Simpulan}

Berdasarkan hasil dari pembahasan dapat disimpulkan bahwa terdapat enam alternatif strategi pengembangan pemasaran pupuk kompos Temesi Organik" yang pertama yaitu meningkatkan kualitas produk untuk menjaga loyalitas konsumen serta sinergisitas kebijakan pemerintah sehingga permintaan terhadap pupuk berkelanjutan. Alternatif strategi kedua yaitu menjaga kontinuitas produk didukung lokasi produksi untuk meraih potensi pasar pupuk organik. Alternatif strategi ketiga yaitu mempertahankan legalitas sertifikasi organik dalam menghadapi persaingan. Alternatif strategi keempat yaitu memperluas jaringan pasar dengan memanfaatkan media sosial serta metode word of mouth marketing. Alternatif strategi kelima yaitu melengkapi sarana dan prasarana produksi agar kualitas bahan baku tetap terjaga dan menekan biaya produksi dalam pengkomposan. Alternatif strategi keenam yaitu meningkatkan kualitas SDM untuk menghasilkan produk dengan posisi tawar yang kuat sehingga mampu bersaing dengan perusahaan sejenis. Prioritas utama strategi pengembangan pemasaran pupuk kompos "Temesi Organik adalah memperluas jaringan pasar dengan memanfaatkan media sosial serta metode word of mouth marketing.

\section{SARAN}

Berdasarkan kesimpulan diatas maka dapat diberikan saran sebagai berikut yaitu diharapkan YPST memaksimalkan penggunaan media sosial dalam upaya memperluas jaringan pemasaran pupuk organik khususnya di Provinsi Bali. Sebaiknya memilih media sosial Facebook dan Instagram untuk memudahkan dalam menemukan berbagai jenis kalangan/segmentasi pasar, serta karena pengaplikasiannya yang sederhana. Yayasan sebaiknya meningkatkan kualitas pupuk kompos "Temesi Organik", pelayanan kepada konsumen agar semakin memuaskan, dan menjaga kontinuitas produk untuk keberhasilan menerapkan metode word of mouth markeing. Diharapkan pemerintah Provinsi Bali berperan sebagai fasilitator untuk mewujudkan kemitraan antara pengusaha atau konsumen dengan petani melalui penguatan lembaga pemasaran dalam rangka menjamin produk organik yang telah dihasilkan oleh petani dapat tersalurkan dengan baik, sehingga penggunaan input pertanian organik salah satunya pupuk akan tetap berkelanjutan.

\section{UCAPAN TERIMA KASIH}

Terima kasih penulis ucapkan kepada jajaran manajemen Yayasan Pemilahan Sampah Temesi karena telah membantu dalam memberikan data pendukung yang diperlukan penulis serta mengizinkan dalam melakukan penelitian, kedua pembimbing yang sudah penuh kesabaran serta ikhlas memberikan bimbingan kepada penulis dalam menyusun tesis ini, segenap dosen dan pegawai Program Studi Magister Agribisnis, Fakultas Pertanian, Universitas Udayana, kedua orang tua penulis atas segala pengorbanan dan jerih payahnya memberikan dukungan moral, dana, dan spiritual yang tiada hentinya diberikan, serta seluruh pihak yang tidak dapat penulis sebutkan satu-persatu, terima kasih atas segala bantuannya.

\section{DAFTAR PUSAKA}

Alma, Buchari. 2000. Manajemen Pemasaran dan Pemasaran Jasa. Cetakan kedelapan Bandung: Alfabeta.

Badan Pusat Statistik. 2017. "Statistik Lingkungan Hidup Indonesia (Environment Statistics of Indonesia 2017'. Jakarta (ID).

Dinas Lingkungan Hidup Daerah Provinsi Bali. 2017. "Status Lingkungan Hidup Daerah Provinsi Bali Tahun 2017”. Denpasar (ID).

Dinas Tanaman Pangan, Hortikutura dan Perkebunan Provinsi Bali. 2018. "Pelaksanaan Subsidi Pupuk Organik Pemerintah Provinsi Bali Tahun Anggaran 2017'. Denpasar (ID).

Fatchur. 2015. Peran Bahasa Inggris dalam Dunia Bisnis. Tersedia: http://p2tel.or.id/2015/10/peran-bahasainggris-dalam-dunia-bisnis/ (diunduh tanggal 7 Mei 2019).

Gitosudarmo, I. 2008. Manajemen Pemasaran. Edisi Kedua. Cetakan Pertama. Yogyakarta: BPFE.

Kardinan, A. 2018. Sistem Pertanian Organik. Jakarta: Intimedia.

Kotler, P. 2002. Prinsip - Prinsip Pemasaran. Edisi Keduabelas. Terjemahan Bon Sabran, MM. Jakarta: Penerbit Erlangga.

Kurttila M, Pesonen M, Kangas J, Kajanus M. 2001. A'WOT: Integrating The AHP With SWOT Analysis. ISAHP 2001. Berne (CH): 189-198.

Pemerintah Provinsi Bali. 2013. Peraturan Gubernur Bali No 16 Tahun 2013 Tentang Subsidi Pupuk Organik kepada Lembaga/Perusahaan untuk Pengadaan dan Penyaluran Pupuk Organik dari Anggaran Pendapatan dan Belanja Daerah Provinsi Bali. Sekretaris Daerah Provinsi. Bali.

Rangkuti, F. 2008. Analisis SWOT Teknik Membedah Kasus Bisnis. Jakarta : PT Gramedia Pustaka Utama. 
Tjiptono, F, Gregorius, C dan Andriana, D. 2010. Pemasaran Strategik. Yogyakarta: ANDI

Umar, H. 2003. Strategic Management in Action. Jakarta: PT. Gramedia Pustaka Utama.

Yayasan Pemilahan Sampah Temesi. 2018. Laporan Tahunan Yayasan (2013-2017). Gianyar (ID).

YPST. 2018. Temesi Recyling Restoring Your Ecosystem. [Internet]. Tersedia: http://temesirecycling.com/id/.

Zulkifli, L. 2017. Strategi Pemasaran Beras Organik pada Kelompok Tani Sri Makmur di Kabupaten Sragen. Program Studi Agribisnis. Sekolah Pascasarjana. [Thesis]. (ID): Institut Pertanian Bogor. 